\title{
Student Teachers' Ways of Thinking and Ways of Understanding Digestion and the Digestive System in Biology
}

\author{
Sabiha Odabaşı Çimer (Corresponding author) \\ Karadeniz Technical University, Trabzon, Turkey \\ Tel: 90-506-235-3945Ｅ-mail: sabihaodabasi@gmail.com
}

\author{
Nazihan Ursavaş \\ Rize University, Rize, Turkey
}

$\begin{array}{lc}\text { Received: January 3, } 2012 & \text { Accepted: January 12, } 2012 \text { Online Published: April 17, } 2012 \\ \text { doi:10.5539/ies.v5n3p1 } & \text { URL: http://dx.doi.org/10.5539/ies.v5n3p1 }\end{array}$

This study was supported by Karadeniz Technical University, Scientific Research Projects Coordination Center.

\begin{abstract}
The purpose of this study was to identify the ways in which student teachers understand digestion and the digestive system and, subsequently, their ways of thinking, as reflected in their problem solving approaches and the justification schemes that they used to validate their claims. For this purpose, clinical interviews were conducted with 10 biology student teachers. According to the data, the student teachers possessed different levels of understanding that can be summarized into three categories: (1) naïve, in that their study method was unscientific and memorization-based, (2) fragmented, and (3) unsound. Their ways of thinking were congruent with their ways of understanding, and this was reflected in their explanations, which were constructed ad hoc and focused on simple linear relationships. In line with these ways of thinking, the justification schemes used by the student teachers were mainly external and empirical schemes, which are considered to be unsophisticated or lower-level. This study is the first study that attempts to reveal and classify student teachers' justification schemes in biology. Earlier studies on student learning processes have been conducted in mathematics. We discovered distinct patterns in the justification schemes used by student teachers, and these patterns were related to the nature of biology as a life science. At the end of the paper, we discuss our results and provide suggestions for teacher education and future research.
\end{abstract}

Keywords: Ways of thinking, Ways of understanding, Digestion

\section{Introduction}

Biology is generally perceived by students as a subject to be memorized (Çimer, 2004). Because students think that biological knowledge is composed of facts to be memorized, they mainly employ low-level thinking skills and only learn facts. In addition, many studies have also shown that students have naïve understandings and could not think multidimensional level (Driver, Squires, Rushworth and Wood-Robinson, 1994; Grotzer and Perkins, 2000; Grotzer and Basca, 2003; Preece and Janvier, 1992; Tamir and Zohar, 1991; White, 2000; Maskiewicz, 2006; Odabaş1 Çimer, 2004). Many researchers in biology education indicate that teacher-centered, memorization-based instructional methods are to blame for these student approaches to biology (Okebukola, 1990; Lin and Hu, 2003; Çimer, 2004). As biology instruction in schools deemphasizes conceptual understanding and stresses rote memorization and students develop alternative conceptions and since they are not provided with the opportunities to express their opinions in lessons, their alternative conceptions can not be determined or challenged (Çimer, 2004). The topics in Biology that students mostly have alternative conceptions and experience difficulties to learn are cell metabolism, circulatory system, homeostasy, reproduction, photosynthesis and respiration, ecology, genetics and digestion system (Songer and Mintzes, 1994; Yip, 1998; Tekkaya, 2002; Prokop and Fancovicova, 2006). Recent studies on alternative conceptions have shown that not only the students at primary and secondary schools but also student teachers of biology share these alternative conceptions and shallow conceptual understandings (Waheed \& Lucas, 1992; Yip, 1998; Tekkaya et al., 2000).

There is considerable evidence suggesting that teachers' knowledge, understanding and thinking skills are linked to student learning and achievement (Ashton, 1988; Goulding, Rowland \& Barber, 2002; Hill, Rowan \& Ball, 2005; 
Mandeville \& Lui, 1997). Thus, in order to improve student learning, understanding and thinking skills, schools of education should first equip student teachers with the necessary knowledge and skills to properly educate their own students when they start teaching. Hence, as Warburton (2008) suggested, the pre-service education training period is an ideal time to carry out interventions that promote effective teaching through challenging and redirecting student teachers' own misconceptions to achieve the desired outcomes.

This study attempted to examine student teachers' existing ways of understanding and their thought processes related to the topics of digestion and digestive system in order to inspire improvements in these areas. Ways of understanding can be defined as the products of mental acts we carry out in our minds. In other words, if we define problem solving, explaining and justifying as mental acts, then ways of understanding can be defined as the solution to a problem, the explanation that one formulates about a phenomenon, or the justification that one provides.

Ways of understanding may differ from one student to another. Students' ways of understanding can be used as a reference point to infer their ways of thinking. Students' ways of understanding in connection with a particular mental act may reflect certain features of that act. These features are labeled as ways of thinking, which can be problem solving approaches, proof (justification) schemes or beliefs about the subject (Harel, 1998).

Therefore in this study, it was assumed that determining student teachers' existing ways of understanding and ways of thinking would enable us to identify appropriate cognitive objectives for instruction. We would then be able to build teaching efforts based on these objectives in order to help student teachers improve their ways of thinking and understanding.

In this study, Harel (1998)'s DNR-based instruction model provided a theoretically grounded way to categorize student teachers' ways of thinking and understanding concerning digestion and the digestive system. This is a topic in biology that is frequently reported poorly understood by students and judged to be difficult by many teachers (Yip, 1998; Tekkaya, 2002).

DNR is an acronym for Duality, Necessity and Repeated Reasoning, the three foundational principles of the model. The Duality Principle of the DNR model indicates that there is a developmental interdependency between one's ways of thinking and ways of understanding (Harel, 1998, 2001). In other words, ways of thinking affect ways of understanding, and vice versa. Thus, in the first phase of the DNR model, ways of thinking and ways of understanding are determined to guide instructional objectives.

Using semi-structured clinical interviews, this study applied the Duality Principle to explore student teachers' existing ways of thinking and ways of understanding digestion and the digestive system. Our objective was to use our results to develop instructional goals, which would guide curricular designs to achieve the desired outcomes in student teacher training.

The achievement of these curricular and instructional goals is related to the Necessity and Repeated Reasoning Principles of the DNR model. According to the Necessity Principle, in order for students to learn, they must experience a genuine intellectual need or internal desire to learn or solve problems. Thus, students should be presented with situations that elicit such needs. The Repeated Reasoning Principle posits that students need to practice problem solving and reasoning in order to develop specific ways of thinking and ways of understanding. This study applied the Duality Principle only; the other two principles fall outside the scope of this study. Therefore, the Duality Principle and the constructs related to this principle are examined below in greater detail.

\subsection{Theoretical Framework}

The DNR-based instructional model provides a theoretical framework to help students develop conceptual knowledge through problem solving. Harel (1998) developed this model in mathematics and introduced it as an instructional method for the development of students' ways of understanding and thinking in mathematics. There are three foundational concepts in the DNR model: mental acts, ways of thinking, and ways of understanding (Figure 1).

Insert Figure 1 here

Harel indicates that there is a developmental interdependency between the ways of thinking and the ways of understanding (Harel, 1998; 2001). In other words, how students come to understand a specific concept affects their ways of thinking and vice versa. Harel defines this relationship as the Duality Principle of DNR-based instruction. He indicates that reciprocity exists between learners' ways of thinking and ways of understanding, and instructional goals should be determined based on these two types of knowledge.

According to Harel (1998), ways of thinking involve problem solving approaches, justification schemes and beliefs about the subject. He defined these ways of thinking for mathematics instruction, but the principle can also be applied to biology. Biological ways of thinking also include problem solving approaches, justification schemes and 
beliefs about biology.

This study examines student teachers' problem solving approaches and justification schemes as their ways of thinking. Beliefs are not included in this study.

Helping students develop problem solving skills is one of the top priorities of science educators. Problem solving approaches are related to a variety of mental acts, such as identifying causes and effects, inferring, explaining, reasoning, analyzing, synthesizing and evaluating, which are considered to be higher-level thinking skills. Biology instruction should help students to develop these skills (Blosser, 1988). Determining student teachers' problem solving approaches, as they related to the mental acts of explaining and identifying causes and effects, was a major goal of this study.

Similarly, proof (justification) schemes are defined as one of the ways of thinking in mathematics to define what convinces a student or what the student offers to convince others of the truth of a claim (Harel, 1998). In biology, Maskiewicz (2006) opted to use the term 'justification scheme' in place of proof scheme 'because of connotations associated with the words 'proof' or 'proving' in science. Nevertheless, the acts of ascertaining and persuading, identified by Harel as comprising the act of proving in mathematics, are compatible with scientists' activity as they try to justify a claim' (2006:50). In the present study, the term 'justification scheme' was also used in place of proof scheme, as the term 'justifying,' as opposed to 'proving,' seems to be more suitable in science to define student teachers' ways of thinking in connection with validating a claim.

Our interpretations of the justification schemes used by the students in this study were based on Harel and Sowder (1998)'s framework for classifying students' proof schemes. They provide a detailed classification of proof schemes with several sub-groups. In this study, we only consider the most basic level of the taxonomy. At this level, proof schemes fall into three categories: external, empirical, and analytical.

In external proof schemes, students appeal to external sources to convince themselves and others. Such external sources can be the word of an authority, such as a textbook, a teacher or another trusted person, the form of an argument, as opposed to its content, or symbols, with no reference to their meanings. Students who employ empirical proof schemes justify their claims using empirical evidence, such as examples, specific cases, or mental images. Finally, in analytical proof schemes, students use logical deductions to validate their claims.

In this study, the above-mentioned categories were used to interpret student teachers' actions when solving the problems presented to them during interviews.

Overall, the main goal of this study was to determine the ways of understanding and thinking that the student teachers provided during the course of interviews in order to provide a basis for establishing specific cognitive goals for instruction. Therefore, the results of this study can be used as a guide to design teaching activities that help learners to develop optimal ways of thinking and to overcome their existing ways of understanding.

In addition, no studies could be cited in the literature, which investigated student teachers' justification schemes in biology. Therefore, this is the first study that attempts to determine and classify student teachers' justification schemes in biology. In this vein, this study will enhance our knowledge of this area in the literature of the field.

We also hope that the results will provide teacher educators and education development agencies with a research basis for planning and administering professional training courses for pre-service biology teachers. This does not imply a generalization of the results; however, they can at least provide a useful starting point.

The research questions posed by the study are:

1) What are the student teachers' ways of understanding digestion and the digestive system in humans?

2) What are the student teachers' ways of thinking in relation to problem solving acts?

3) What kinds of justification schemes do the student teachers use to validate their claims?

\section{Methodology}

\subsection{Participants}

The sample of the study consisted of ten student teachers of biology, who were in the last year of their pre-service teacher education course at Karadeniz Technical University. Out of the 30 student teachers in the class, these ten student teachers volunteered to participate in the study.

\subsection{Method and Data Collection}

This study was a small-scale survey that investigated student teachers' ways of thinking and understanding concerning digestion and the digestive system. The data for the study were collected through semi-structured clinical 
interviews.

Semi-structured clinical interviews are considered to be an effective method for determining participants' thinking and mental processes, as it allows participants think out loud (Clement, 2000). In addition, it allowed us to probe participants' thought processes and encourage them to consider areas that they might otherwise not have thought about or shared.

The interviews were conducted one-on-one with the student teachers, and all of the interviews were tape-recorded. The goal of the interviews was to determine the participants' ways of understanding and thinking when they were engaged in solving problems about digestion and the digestive system.

During the interviews student teachers were presented with five problem situations about digestion and digestive system, which were prepared based on the literature and through discussions with two biologists. The student teachers were asked to explain or produce a solution and were also asked to think aloud. They were probed to provide detailed explanations so that we could uncover their existing ways of understanding and ways of thinking about digestion and the digestive system. In order to reveal student teachers' justification schemes, they were also asked how they made sure that their claims were true.

\subsection{Data Analysis}

The data from the interviews provided qualitative data on the student teachers' ways of understanding and ways of thinking. The raw data from the tape-recorded interviews were transcribed verbatim as soon as possible and then recorded on the computer using word processing. The transcripts were read and re-read carefully several times to identify student teachers' ways of understanding and to make inferences concerning their thought processes based on their ways of understanding. The classification of the student teachers' justification schemes was made based on Harel and Sowder (1998)'s proof schemes model. The two researchers conducted this analysis separately and, afterwards, the results were compared and discussed. Consensus was reached on all items.

Throughout the report, each student teacher is identified as Student Teacher (ST), followed by a number, to protect the participants' identities.

\section{Results}

Our results and discussions are grouped into three subheadings corresponding to the following research questions: (1) What are the student teachers' ways of understanding in relation to digestion and the digestive system? (2) What are the student teachers' ways of thinking in relation to problem solving acts? and (3) What kind of justification schemes do student teachers use to validate their claims?

\subsection{Student Teachers' Ways of Understanding}

During the interviews, the student teachers were presented with problem solving situations in order to reveal their understandings of digestion and the digestive system. According to our analysis of the data, the student teachers' ways of understanding about the functions of the digestive organs and the process of digestion can be grouped into the following categories: (1) naïve or simplistic in terms of being unscientific and memorization-based, (2) fragmented, and (3) unsound.

All of the student teachers possessed naïve conceptualizations of the stomach. When asked in the interview 'what happens if someone's stomach has been removed?,' they reported varying responses, most of which were unscientific. Two of the student teachers thought that the stomach could regenerate itself; 'The stomach can regenerate itself... for example, if a person has two-thirds of his or her stomach removed, it will grow back to its original size' (ST 7).

Another student teacher also claimed that the stomach could renew itself, citing the experience of one of her friends to justify her claim:

A friend of mine had stomach cancer. A part of her stomach had been surgically removed.

She subsisted on a liquid diet for 4-5 years. However, after 4-5 years, her stomach renewed itself and grew back to its original size. But, for about 4-5 years, she was only able to consume liquid food (ST 5).

The epithelial lining of the stomach can regenerate itself, but this is not the same as partial or complete regeneration of the stomach. In addition, tissue engineering studies on the reconstruction of stomach are still ongoing (Hori et al., 2002).

Two of the student teachers claimed that one could not live without a stomach. One said; '...what happens to $a$ person whose stomach has been removed?... I think they place a new stomach there. One cannot live without a stomach. I think they cannot live' (ST 4). 
The others also expressed naïve or inaccurate and unscientific ideas, such as the possibility of developing a stomach-like structure from the small intestine or even from the large intestine.

ST 4: Because the stomach is linked to the small intestine, a stomach-like structure develops from the small intestine.

Researcher: O.K., what is the function of the stomach? Can the small intestine perform the same functions?

ST 4: Digestion... the small intestine performs the same function, digestion.

The student teachers also seemed to be confused about the functions of the gallbladder and the liver. When asked about the function played by the gallbladder in the digestion process, most of the student teachers talked about the digestion of fats, but they seemed either unsure about their answers or they did not know the details. In addition, most indicated that bile was secreted in the gallbladder. Below is an example from the interview with ST 3;

Researcher: What is the function of the gallbladder during the digestion process?

ST 3: I think it helps in the digestion of fats. But I don't know the details.

Researcher: Where do you think bile is secreted?

ST 3: In the gallbladder.

The ways in which the student teachers understood the digestion process were also problematic. Their answers showed that their understanding was unscientific, unsound and fragmented.

In many cases, the student teachers seemed to be unsure about the accuracy of their answers. In these cases, the student teachers provided answers in the form of a question, or immediately after making a claim, they asked questions seeking confirmation from the researcher. These responses were grouped together as 'unsound ways of understanding' in this study. Below is an example of this:

Researcher: What happens to a person whose gallbladder has been removed?

ST 2: It is responsible for the digestion of fats, am I right? How will they be digested? Does the liver takes over its functions?

Researcher: Why the liver?

ST 2: Because they are connected.

Researcher: How are they connected?

ST 2: Certain minerals are broken down by bile stones, aren't they?

Fragmented ways of understanding were apparent in responses showing that the respondent possessed a certain degree of knowledge, but that knowledge was incomplete. Most of the student teachers indicated that mechanical digestion only takes place in the mouth. In addition, two of the student teachers claimed that the stomach was responsible for chemical digestion only. They also indicated that because the stomach was responsible for the digestion of proteins and fats, if someone's stomach had been removed, s/he could not consume food containing protein or fat.

A significant number of student teachers also revealed naïve and fragmented understandings of the enzymes aiding digestion. They all knew that enzymes performed important functions in the digestion process, but they lacked knowledge of what happened to the enzymes after they had performed their function. The student teachers frequently claimed that 'the enzymes disappear,' and two student teachers said that the enzymes were 'used up' during the reactions.

The following figure presents a summary of the student teachers' conceptualizations of these processes.

Insert Figure 2 here

\subsection{Student Teachers' Ways of Thinking}

Learners' ways of thinking are defined as the characteristics of their mental acts (Harel, 1998). In this study, the student teachers were presented with situations that were intended to cause them to engage in mental acts such as explaining and identifying relationships, and they were further probed to explain and justify their answers. The ways of thinking that they were expected to possess were problem solving approaches and justification schemes.

Therefore, in this section, data on the student teachers' ways of thinking are grouped into two main categories: (1) problem solving approaches (the manners in which students used such mental acts as explaining and identifying relationships) and (2) justification schemes that the student teachers used for validation. 


\subsubsection{Student Teachers' Problem Solving Approaches}

According to the results of our analysis, the student teachers' ways of thinking as reflection in their problem solving approaches can be grouped into two categories in relation to the mental acts of explaining and identifying relationships: (1) ad hoc / improvised accounts and (2) a focus on simple linear relationships rather than the consideration of multiple and complex relationships.

Based on our analysis of the data, we concluded that most of the explanations provided by the student teachers were ad hoc or improvised. In other words, their responses seemed to be based on what made sense to them in the moment. During the interviews, they provided answers to the questions but, when probed further, they could not provide details and frequently used the phrases like 'I don't know the details' or 'I can't remember it right now.' Below are some examples of the responses provided by the student teachers during their interviews:

Researcher: What is the function of gallbladder?

ST 8: I think it helps in the digestion of fats. I don't know the details.

ST 10: I can't remember if the bile is responsible for the digestion of fats. The stomach can be too, but mostly enzymes in the bile are responsible, as far as I know.

ST 7: I guess the gallbladder secretes an enzyme to aid in the digestion of fats. The following responses were provided by ST 7 in answering another question:

Researcher: Why there is no enzyme in the medium after the food has been digested?

ST 7: Enzymes are responsible for breaking down the food. If there is no food, they are in the inactive form.

Researcher: O.K., they may be in the inactive form. But why there is no enzyme?

ST 7: I have no idea.

Researcher: Why? Has this not been covered in your lessons?

ST 7: I don't know. It might be... but... I have never thought about why they are not there after digestion.

Such responses imply that student teachers mainly relied on memorized knowledge, which is insufficient to provide detailed explanations. In the above example, ST 7 initially provided the first answer that came to her mind, but, when probed further, she acknowledged that she did not know, adding that she had never thought about it before. This may also be because she did not need to think about it in her lessons. The response of, 'I have never thought about why they are not there after digestion' can also be used as a clue indicating that the biology instruction with which she had been provided was content oriented and based on memorization.

The responses provided by the student teacher in the following dialogue reflect a similar situation. She first tried to explain her responses, but then gave up because of her lack of knowledge.

Researcher: Why do you think there is no enzyme after food has been digested?

ST 2: Enzymes cannot be reused. I mean, they are used up and finished.

Researcher: What do you mean? What happens to the enzyme?

ST 2: I think they are deactivated or something else, I do not know. First they are used up, and then, when they are required again, they are produced.

Researcher: How is it used up?

ST 2: For example, food goes into the stomach and there was something there... was it $\mathrm{HCl}$ ? I cannot remember right now. Anyway, say an enzyme... it is used up, finishes...No...O.K., I don't know that.

Based on the above episode, it can be said that ST 2's explanations were constructed ad hoc. She first said that 'the enzymes are used up' during the reactions and, when asked for further explanation, she changed her responses and said that they might be deactivated. Afterwards, she tried to explain by drawing on information she had memorized, but she was unsuccessful.

Two student teachers indicated that the enzymes might be broken down after they had done their job. However, when pressed further, they seemed unsure and provided improvised explanations:

Researcher: Why are there no enzymes present after they have done their job?

ST 4: It might be because they are reversible. 
Researcher: What do you mean by that?

ST 4: Enzymes are broken down and disappear... An enzyme is a compound secreted only when it is needed.

Researcher: What do you mean by 'disappear'? Where do they go?

ST 4: After they are broken down, they are sent away. Then, when they are needed, they appear. But I do not know where they are sent to.

Consequently, student teachers mostly developed explanations based on the information that made sense to them at the moment. Most of their explanations were constructed ad hoc and were insufficient to account for all aspects of the phenomena. When probed further, some changed their responses and could not provide detailed accounts, mainly due to their lack of knowledge.

In addition, student teachers' responses mainly focused on simple linear relationships, disregarding the complex interrelationships between the systems or the elements of the digestion process. In their answers, they tended to identify specific direct causes.

During the interviews, student teachers were asked about the interrelations between the systems, and they were expected to provide explanations. One of the questions asked, 'When we broke down the food into very tiny pieces and injected it directly into a guinea pig's blood, the guinea pig died. Why?' In their responses to this question, the student teachers were expected to provide explanations indicating the relationship between the digestive and immune systems. However, only one of the student teachers was able to point out this relationship in her response. But she could not provide a satisfactory explanation, and she also did not seem to be sure about her response. The following segment is from this student teacher's interview:

ST 2: The reason is antigen-antibody reactions in the blood.

Researcher: Can you explain it further?

ST 2: How can it be transferred?... How can solid food be transferred in the blood? (She seemed confused)

Researcher: But, they are very tiny pieces.

ST 2: I didn't think of it that way. Why did it die?... If the guinea pig died, then there is something wrong. It should be the antigen-antibody reaction.

Researcher: What happens during the antigen-antibody reaction?

ST 2: I knew that, but I can't remember now.

Obviously, this student teacher relied on memorized knowledge. In her response, she mentioned the antigen-antibody reaction, although she did not know what it meant. She did initially provide the correct response; however, later in the interview it became clear that she had just provided an answer without properly thinking about it, and the mental act that she used did not go beyond guessing.

Regarding this question, the other student teachers' responses also tended to focus on simple linear relationships and specific direct causes, and their answers also included improvised statements.

Two of the student teachers indicated that food injected into the bloodstream might burst the blood vessels, resulting in the guinea pig's death. The following account is representative of these student teachers' responses:

ST 1: If we injected undigested food directly into the bloodstream, there is nothing in the blood to digest the food.

Researcher: O.K., what happens?

ST 1: I'll use my imagination. I think that if we inject the food directly into the bloodstream, it may burst the blood vessels.

Similarly, the other student teachers also sought direct causes for the death of the guinea pig. Their claims mainly implied the body would not benefit from the injected food and, because of that, death occurred.

ST 5: The food might have been broken down into very tiny pieces, but it had not been broken down by the enzymes. It can't enter into the cells. Since we did not break it down to its building blocks, it can't be taken by the cells and the guinea pig can't be fed. And, because of that, death occurs.

Researcher: Do you think that is the only reason?

ST 5: Because the guinea pig can't be fed. There might be other reasons, but this is what came to my 
mind first.

Overall, most of the responses provided by the student teachers clearly indicate that they relied on recall to generate explanations. They provided responses based on what made sense to them at the moment and, when probed further, they admitted that they could not remember or did not know. Their responses were mainly based on simple linear thinking, and they did not consider multiple relationships. As indicated earlier, the situations presented or the questions posed to the student teachers during the interviews required the use of mental acts such as explaining and identifying relationships between concepts, which are higher order thinking skills and cannot be achieved through rote memorization.

\subsubsection{Student Teachers' Justification Schemes}

The data in this section provide evidence regarding the justification schemes used by the student teachers for verification. We used the framework proposed by Harel and Sowder (1998) to identify which of the three main proof schemes (external, empirical, and analytical) could be used to classify the student teachers' responses.

As shown in Table 1, the majority of the student teachers' responses were classified under the externally based and empirical justification schemes. Only two of the student teachers used analytical schemes in this study. As Harel and Sowder (1998) indicated, these categories are not mutually exclusive, and one student teacher could utilize more than one kind of scheme.

\section{Insert Table 1 here}

Data on each justification scheme are presented and discussed below.

External scheme: The student teachers in this study most often used externally based schemes to justify their responses. They mainly based their arguments on what their textbooks, instructors or parents said. In the following dialogue, the student teacher pointed to what her teacher had said to justify her argument:

Researcher: You said, 'If someone's gallbladder is removed, the liver takes over its function.' How can you be sure of this?

ST1: One of my teachers told me.

Researcher: Did you do any research on that later?

ST 1: No. When I have a question, I ask my teachers, and I don't forget what they say. I learn better this way.

Researcher: O.K... Have you ever conducted research to discover an answer independently?

ST 1: ...I don't remember.

Another student teacher pointed to his father as the authority to justify her claim;

Researcher: What happens if someone's stomach is removed?

ST 2: The stomach regenerates itself.

Researcher: How does the stomach do that?

ST 2: I know that because of my family. My father told me, and he is a biologist.

Such comments were frequently made by the student teachers during the interviews. As indicated by the above dialogues, the student teachers were accustomed to accepting what their teachers or parents said as true, and they did not see any need to inquire further. This indicates that they simply memorize the facts rather than constructing their own knowledge. However, memorizing facts does not produce the necessary understanding of the underlying concepts, as evidenced by the above results.

Empirical scheme: Another type of scheme used by the student teachers in the study to justify their accounts was the empirical scheme. The nature of the empirical schemes most often used by the biology student teachers in this study differed from those identified by Harel and Sowder (1998) in mathematics. Our results demonstrated distinct patterns more suited to the nature of biology and biological knowledge.

Biology is the science of life. It is closely related to life and helps us understand and explain the world around us. Because of the nature of biology, the student teachers in this study frequently used examples from daily life to justify their assertions. We have labeled this new type of scheme the 'experience-based scheme'.

All but two of the student teachers whom we interviewed used experience-based schemes. The following examples are taken from the interviews of ST 6 and ST 7:

Researcher: What happens if someone's gallbladder has been removed? 
ST 6: I know someone whose gallbladder has been removed, and she lives without any complications. But she is very fat. I think it is because her gallbladder was removed.

ST 7: My mum's gallbladder has been removed. She used to have tummy aches and discomfort after meals. Then, her doctor said that her liver had increased in size. She did not have that problem before she had her gallbladder removed. Thus, I think that they are related.

Analytical Scheme: Analytical schemes are the advanced form of proof schemes. Learners who use this kind of scheme justify their claims through logical deductions. In this study, this category of scheme was used least often by the student teachers. We could only identify two cases in which the student teachers used this scheme. Rather than resorting to external or experience-based schemes, these student teachers tried to draw conclusions based upon what they knew about the topic at hand. An important point here is that, although their thinking processes reflected the use of the analytical scheme, the answers they provided to the questions were not as sophisticated as they should have been. Below is an example from ST 4's interview. Her analytical thinking process did not go beyond considering simple linear relationships.

Researcher: When we broke down the food into very tiny pieces and directly injected it into a guinea pig's blood, the guinea pig died. Why?

ST 4: Larger food molecules are digested into monomers and then transported into the blood. Cells can't use them (injected food). I mean, we can't do chemical digestion outside of the body. I mean, as there is no chemical digestion, cells can't use the food. They can't convert food into energy. Therefore, I think, the guinea pig dies.

The following example is taken from another student teacher's (ST 2) interview. She was asked the same question, and her response regarding the reason for the death of the guinea pig was 'antigen-antibody reaction'. She did provide the correct answer, but she was not able to explain the relationships between the biological processes. However, her justification of her response can be classified as a logical deduction.

Researcher: O.K. How can you be sure that this is because of antigen-antibody reaction?

ST 2: Since the guinea pig died, it should be something related to the blood. There should be something wrong. Because the food is injected into the blood. If the guinea pig died, then there is something wrong with the blood.

\section{Discussion and Conclusions}

The purpose of this study was two-fold. First, we sought to identify student teachers' existing ways of thinking and ways of understanding digestion and the digestive system based on the Duality Principle of Harel's DNR-based model of instruction. Our second goal was to determine and classify the justification schemes (one category of ways of thinking) that biology student teachers used to show that their claims were true. This second goal represents a previously unexplored area of research in the field.

To achieve these aims, clinical interviews were conducted with ten student teachers of biology who were in the last year of their pre-service education. The results supported the claim that the ways of understanding demonstrated by student teachers were related to their ways of thinking. The student teachers employed different ways of understanding, which we have defined as (1) naïve, in terms of being unscientific and memorization-based, (2) fragmented, and (3) unsound. Their ways of thinking, in relation to the mental acts of explaining and identifying relationships, were congruent with their ways of understanding, and this was reflected in the explanations they provided, which were constructed ad hoc and focused on simple linear relationships. The responses that they provided to the questions were mostly based on what made sense to them at the moment and were not well thought out.

In their explanations of the problems that we presented to them, the student teachers mostly relied on memorized knowledge and could not reason or identify relationships between the concepts. They often provided correct answers to the questions, but when probed further, they could not provide an explanation because they had learned via memorization without understanding the relationships or underlying concepts. Similar observations were reported by Bhattacharyya and Bodner (2005), who demonstrated that the graduate students in their study could produce correct responses to problems via memorization without understanding the chemical concepts behind their solutions.

Most of the student teachers' justification schemes exhibited the same limitations, as did their approaches to giving explanations and identifying relationships; most of them did not go beyond empirical schemes. They mainly justified their claims with less sophisticated or naïve justification schemes, such as external and empirical.

An important result of this study is the identification of a new category of schemes, which we have labeled 
'experience-based schemes.' This type of scheme is different from those defined by Harel and Sowder (1998) in mathematics. The category of experience-based schemes became evident when the student teachers in this study appealed to daily life examples or experiences to justify their claims. We believe that this scheme is more suited to biology as a life science.

Only two of the student teachers used analytical schemes to justify their answers. However, an important point that should be emphasized here is that their analytical justifications were used to explain simple logical deductions. They also focused on simple linear relationships or direct causes, disregarding non-linear or multiple relationships. The conclusions they reached were mostly naïve or incorrect. Figure 3 below summarizes the relationship between the student teachers' ways of understanding and ways of thinking.

Insert Figure 3 here

Similar results have been reported in the literature. Various studies on students' thinking skills have reported that students possessed naïve understanding and employed undesirable ways of thinking (Driver, Squires, Rushworth, and Wood-Robinson, 1994; Grotzer and Perkins, 2000; Grotzer and Basca, 2003; White, 2000, Maskiewitcz, 2006). Maskiewitcz (2006), working with undergraduate students, reported that the students' ways of thinking before implementation of the DNR-based model of instruction were one-dimensional and focused on simple linear relationships. In relation to this, their ways of understanding were also naïve and unscientific. In addition, Schroeder (2007), who researched students' ways of understanding, reported that students' conceptualizations of the digestive system were unscientific.

It seems that the source of students' information or the way in which they learn a particular subject determines how they understand it. Researchers have indicated that two important sources of students' unscientific conceptions are daily life and formal learning events (Straus, 1981; Osborne and Cosgrove, 1983; Soyibo, 1995). In this study, the student teachers mostly mentioned external schemes, such as what teachers or parents told them, and examples from their daily environment, which we labeled as 'experience-based schemes,' to support their claims. In the end, externally based information or information gleaned from daily experiences may not accord with scientific knowledge, and these types of knowledge are not sufficient to enable students to construct a scientific conceptualization.

An important point that should be taken into account regarding the results of this study is that the student teachers with such naïve and unscientific understandings and undesirable thinking skills are in the last year of their pre-service education and will soon be teaching pupils in schools. If they do not know how to explain concepts, reason or solve problems, how can one expect them to improve such skills in their students? Thus, this study carries important implications for teacher education courses at both the pre-service and in-service levels.

The education in our schools has always been criticized for being teacher-centered and based on rote learning. Despite the reform efforts ongoing for last decade and designed to implement constructivist learning and teaching in schools, the tradition of memorization-based teaching and learning obviously still persists. This is supported by the student teachers' responses, which reflected their naïve and unsophisticated thinking process. There is a relationship between the way students are taught and the way they think (Grotzer and Basca, 2003). Because the instruction in schools relies on simple linear relationships and does not provide opportunities for students to consider non-linear relationships, it is to be expected that students, or, in this case, the student teachers, develop this type of thinking.

Because of the pressure to perform well on external tests, such as the University Entrance Exam (OSS), test-based education in secondary schools and its effects on students' learning has always been the main topic of discussions on education in Turkey. Since the implementation of KPSS, a test that every student teacher has to pass after graduation in order to be appointed as a teacher, test-based education has also become a concern at the university level. Hence, there is always pressure at every educational level to prepare students to perform well on standardized tests. Due to these external pressures, it is difficult to help students develop their conceptual understanding and the skills of explanation and problem solving.

In order for students to develop sophisticated thinking skills, they need to understand scientific concepts and their relationships with other concepts. However, students generally believe that biology is a set of truths, and they have a tendency to rely on memorization when learning topics in biology. They need to be taught that knowing or understanding particular 'facts' is not sufficient to learn biology.

How can we teach students desirable ways of thinking? Would telling students that learning a particular biological concept was important for their lives or future careers prove sufficient to make them pay attention? Research suggests that, in order to learn and maintain any skill, students need to be provided with opportunities to practice the skill in lessons (Joyce and Showers, 1983; Frederiksen, 1984). Research has also indicated that one-time exposure to 
a particular skill does not result in learning. Therefore, students should be introduced to the skill and provided with continuous guidance and immediate feedback until they achieve mastery.

Hence, students should be provided with opportunities to reason and engage in problem solving tasks to improve their ways of thinking. As students may develop many undesirable ways of thinking during the early years of schooling, such efforts should begin as early as primary school and continue throughout the schooling years.

However, teaching thinking skills alone may not be sufficient to enable them to put those skills into practice. The ability to reason, solve problems and use one's acquired knowledge in new situations is closely related to the content knowledge competency. (Mayer, 2003; Spiro et al., 2003). Research comparing the conceptual thinking employed by novices and experts in problem solving indicates that the reason for experts' greater competence is, for the most part, due to the experts' large, well-organized domain-specific knowledge structures (Kinneat \& Simmons, 1990; Hackling, 1994; Mayer, 2003; Spiro et al., 2003; Maskievitcz, 2006). Clearly, the learner's initial knowledge structure plays an important role in his or her ability to reason and solve problems. Therefore, it seems likely that, in this study, the student teachers' inability to employ the desired thinking skills and more sophisticated justification schemes could be a result of their lack of a sound knowledge base. In this vein, it is important to review teacher education courses to ensure trainees have sufficient domain-specific knowledge at the end of their course.

This study was limited to investigating ten student teachers' ways of understanding and thinking through presenting them with problem solving situations during clinical semi-structured interviews. Thus, our conclusions are limited to the particular student teachers and problems used in this study. Future studies investigating similar constructs may find that students employ different ways of thinking and ways of understanding. If presented with different problems, participants in other studies may also be found to use analytical schemes, which were rarely used by this study's participants.

Research on learners' ways of understanding, ways of thinking and, especially, justification schemes in biology are relatively new topics. This study attempted to determine student teachers' existing ways of understanding and ways of thinking. Future studies may be designed to take these concepts further to develop optimal ways of thinking and understanding in learners through, for example, implementing the DNR-based instruction model in biology. In terms of determining and classifying learners' justification schemes in biology, this study is the first of its kind. Similar studies could be designed to confirm and enrich our results.

\section{References}

Ashton, P. (1988). Teaching Higher-Order Thinking and Content: An Essential Ingredient in Teacher Preparation. Gainesville, FL: University of Florida.

Bhattacharyya, G., \& Bodener, G. M. (2005). It gets met o the product: How students propose organic mechanisms. Journal of Chemical Education, 82, 1402-1407. http://dx.doi.org/10.1021/ed082p1402

Blosser, P.E. (1988). Labs - Are They Really as Valuable as Teachers Think They Are? Science Teacher, 55(5), 57-59.

Çimer, A. (2004). A study of Turkish biology teachers' and students' views of effective teaching in schools and teacher education. EdD Thesis, The University of Nottingham School of Education, Nottingham, U.K.

Clement, J. (2000). Analysis of clinical interviews: Foundations and model viability. In A. Kelly \& R. Lesh (Eds.), Handbook of Research Design in Mathematics and Science Education (pp. 547-589). Mahwah, NJ: Lawrence Erlbaum Associates.

Driver, R., Squires, A., Rushworth, P., \& Wood-Robinson, V. (1994). Making sense of secondary science: Research into children's ideas. London and New York: Routledge.

Frederiksen, N. (1984). 'The Real Test Bias: Influences of Testing on Teaching and Learning, American Psychologist, 39(3), 193-202. http://dx.doi.org/10.1037//0003-066X.39.3.193

Goulding, M., Rowland, T., \& Barber, P. (2002). Does it matter? Primary teacher trainees' subject knowledge in $\begin{array}{lllll}\text { mathematics, British Educational Research } & \text { Journal, }\end{array}$ http://dx.doi.org/10.1080/0141192022000015543a

Grotzer, T.A., \& Basca, B.B. (2003). Helping students to grasp the underlying causal structures when learning about ecosystems: How does it impact understanding? Journal of Biological Education, 38(1), 16-29. http://dx.doi.org/10.1080/00219266.2003.9655891

Grotzer, T.A., \& Perkins, D.N. (2000). The teaching of intelligence: A performance conception, In R. Sternberg (Ed.) Handbook on Intelligence. New York: Cambridge University Press. 
Hackling, M. W. (1994). Using a V-map to structure prelab and postlab discussions. Australian Science Teachers Journal, 40 (4), 57-58.

Harel, G. (1998). Two Dual Assertions: The First on Learning and the Second on Teaching (or Vice Versa). The American Mathematical Monthly, 105, 497-507 http://dx.doi.org/10.2307/2589401

Harel, G. (2001). The Development of Mathematical Induction as a Proof Scheme: A Model for DNR-Based Instruction. In S. Campbell \& R. Zaskis (Eds.). Learning and Teaching Number Theory. Ablex Publishing. Westport, Conn. p 185-212.

Harel, G. (2006). The DNR system as a conceptual framework for curriculum development and instruction. In R.

Harel, G., \& Sowder, L. (1998). Students' proof schemes: Results from exploratory studies. In A. H. Schoenfeld, J. Kaput, \& E. Dubinsky (Eds.), Research in Collegiate Mathematics Education. III (pp. 234-283). Providence, RI: American Mathematical Society.

Harel, G., \& Sowder, L. (2005). Advanced Mathematical-Thinking at Any Age: Its Nature and Its Development, Mathematical Thinking and Learning, 7, 27-50. http://dx.doi.org/10.1207/s15327833mt10701_3

Hill, H.C., Rowan, B., \& Ball, D.L. (2005). Effects of teachers' mathematical knowledge for teaching on student achievement. American Educational Research Journal, 42(2), 371-406. http://dx.doi.org/10.3102/00028312042002371

Hori, Y. Rulifson, I.C., Tsai, B.C., Heit, J. J., Cahoy, J.D., \& Kim, S.K. (2002). Growth inhibitors promote differentiation of insulin-producing tissue from embryonic stem cells. Proc. Natl. Acad. Sci. USA, 99: 16105-16110. Epub 2002 Nov 19. http://dx.doi.org/10.1073/pnas.252618999

Joyce, B., \& Showers, B. (1983). The coaching of teaching. Educational Leadership, 40(1), 4-10.

Kelly \& R. Lesh (Eds.). Handbook of Research Design in Mathematics and Science Education (pp. 547-589). Mahwah, NJ: Lawrence Erlbaum Associates.

Kinnear, J.F., \& Simmons, P.E. (1990). 'Expert' and 'novice' subjects' approaches to genetic problem solving in a computer-based setting. Research in Science Education, 20(1), 171-180. http://dx.doi.org/10.1007/BF02620492

Lesh, J. Kaput, E. Hamilton \& J. Zawojewski. Foundations for The Future: The Need for New Mathematical Understandings \& Abilities In The 21st Century. Hillsdale, NJ: Lawrence Erlbaum.

Lin, C., \& Hu, R. (2003). Students' understanding of energy flow and matter cycling in the context of the food chain, photosynthesis, and respiration. International Journal of Science Education, 25(12), 1529-1544. http://dx.doi.org/10.1080/0950069032000052045

Mandeville, G. K., \& Liu, Q. (1997). The effect of teacher certification and task level on mathematics achievement. Teaching and Teacher Education, 13 (4), 397-407. http://dx.doi.org/10.1016/S0742-051X(96)00031-5

Maskiewicz, A.L. (2006). Rethinking Biology Instruction: The Application of DNR-based Instruction to the Learning and Teaching of Biology. Unpublished PhD Thesis. California: University of California, San Diego.

Mayer, R.E. (2003). The promise of multimedia learning: Using the same instructional design methods across different media. Learning and Instruction, 13 (2), 125- 139.

McMillan, J.H., \& Schumacher S. (2006). Research in Education: Evidence-Based Inquiry, (Sixth Edition), (21-26), Boston, Pearson Education Inc.

Odabaş1 Çimer S. (2004). An Investigation into Biology Teachers' Perceptions of Classroom Assessment in Secondary Schools in Turkey. University of Nothingam, U.K., Unpublished EdD Thesis

Okebukola, P.A. (1990). Attaining meaningful learning of concepts in genetics and biology: An examination of the potency of concepts of concept mapping techniques. Journal of Research in Science Teaching, 27(5), 493-504. http://dx.doi.org/10.1002/tea.3660270508

Osborne, R., \& Cosgrove, M. (1983). Students' conceptions of the changes of states of water. Journal of Research in Science Teaching, 20(9), 825-838. http://dx.doi.org/10.1002/tea.3660200905

Schönborn, K.J., \& Bögeholz, S. (2009). Knowledge transfer in biology and translation across external representations: Experts' views and challenges for learning. International Journal of Science and Mathematics Education, 7(5), 931-955. http://dx.doi.org/10.1007/s10763-009-9153-3

Schroeder, C. (2007) Inquiring into the digestive system, Science Scope, 31(3), 30-34. 
Songer, C. J., \& Mintzes, J.J. (1994). Understanding cellular respiration: An analysis of conceptual changes in college Biology. Journal of Research in Science Teaching, 31(6), 621-637. http://dx.doi.org/10.1002/tea.3660310605

Soyibo, K. (1995). Using concept maps to analyze textbook presentations of respiration. The American Biology Teacher, 57(6), 344-351.

Spiro, R. J., Collins, B. P. Thota, J. J., \& Feltovich, P. J. (2003). Cognitive flexibility theory: Hypermedia for complex learning, adaptive knowledge application, and experience acceleration. Educational Technology: 44(5), $5-10$.

Strauss, S. (1981). Cognitive Development In School And Out. Cognition, 10, 295-300. http://dx.doi.org/10.1016/0010-0277(81)90060-3

Tekkaya, C., Çapa, Y., \& Yılmaz, Ö. (2000). Pre-service Biology Teachers’ Misconceptions about Biology. Journal of Hacettepe University, 18, 140-147.

Waheed, T., \& Lucas, A. M. (1992). Understanding interrelated topics: photosynthesis at age 14. Journal of Biological Education, 26(3), 193-200. http://dx.doi.org/10.1080/00219266.1992.9655272

Warburton, E.C. (2008). Changes in dance teachers' beliefs about critical-thinking activities, Journal of Education and Human Development, 2(1), 1-16. http://dx.doi.org/10.1080/15290824.2008.10387353

Weber, R. P. (1990). Basic Content Analysis (second edition). Thousand Oaks, CA: Sage.

White, P.A. (2000). Naïve analysis of food web dynamics: A study of causal judgment about complex physical systems. Cognitive Science, 24 (4), 605-650. http://dx.doi.org/10.1016/S0364-0213(00)00032-X

Yip, D. Y. (1998). Teachers' Misconceptions of the Circulatory System. Journal of Biological Education, 32(3), 207-216. http://dx.doi.org/10.1080/00219266.1998.9655622

Table 1. Student teachers' justification schemes

\begin{tabular}{llll}
$\boldsymbol{S T}$ & $\begin{array}{l}\text { External } \\
\text { (Authoritarian) }\end{array}$ & $\begin{array}{l}\text { Experimental } \\
(\text { Experience-based) }\end{array}$ & Analytical \\
\hline $\mathbf{1}$ & + & + & \\
\hline $\mathbf{2}$ & + & + & + \\
\hline $\mathbf{3}$ & + & + & + \\
\hline $\mathbf{4}$ & + & & \\
\hline $\mathbf{5}$ & + & + & \\
\hline $\mathbf{6}$ & + & + & \\
\hline $\mathbf{7}$ & + & + & \\
\hline $\mathbf{8}$ & + & & \\
\hline $\mathbf{9}$ & + & + & \\
\hline $\mathbf{1 0}$ & + & + &
\end{tabular}

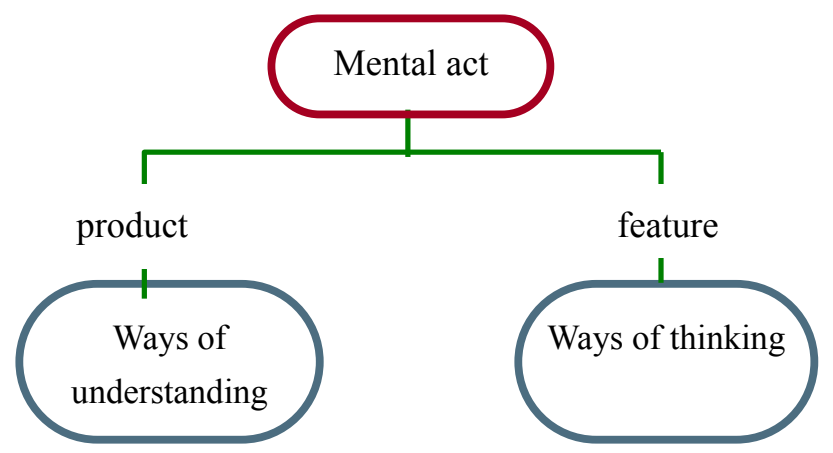

Figure 1. The triad of determinands: Mental act, ways of understanding, ways of thinking (based on Harel, 1998). 
- Mechanical digestion takes place only in the mouth.

- Only chemical digestion takes place in the stomach

- If one's stomach has been removed, s/he can not live

- If one's stomach has been removed, s/he should consume liquid food only

- If someone's stomach has been removed, a stomach-like structure develops from the small / large intestine

- Digestion of protein and fats takes place in the stomach

- Stomach can regenerate itself completely

- Bile is secreted in the gallbladder

- If the gallbladder is removed, fats can not be digested.

- Digestive anzymes are used up during the reactions

Figure 2. Student teachers' ways of understanding

\begin{tabular}{|l|l|l|}
\hline Ways of understanding \\
- $\begin{array}{l}\text { Naive } \\
\text { - Fragmented } \\
\text { Unsound }\end{array}$
\end{tabular}

Figure 3. Student teachers' ways of understanding and ways of thinking in biology 